\title{
Assessment of the Quality of Diesel Fuel from Some Selected Filling Stations in Tarkwa, Ghana
}

\author{
Broni-Bediako $\mathrm{E}^{1 *}$, Amorin $\mathrm{R}^{1}$ and Mensah-Ametum $\mathrm{G}^{2}$ \\ ${ }^{1}$ Department of Petroleum Engineering, University of Mines and Technology (UMaT), Tarkwa, \\ Ghana \\ ${ }^{2}$ Graduate, University of Mines and Technology (UMaT), Tarkwa, Ghana
}

*Corresponding author: Eric Broni-Bediako, Department of Petroleum Engineering, University of Mines and Technology (UMaT), Tarkwa, Ghana, Tel: +233243052455; Email: ebroni-bediako@umat.edu.gh

\section{Research Article \\ Volume 4 Issue 5}

Received Date: October 03, 2020

Published Date: October 30, 2020

DOI: $10.23880 /$ ppej-16000239

\section{Abstract}

Automobile fuel quality is becoming a subject of concern across the world and particularly in Ghana because of potential problems associated with poor quality fuel. Poor quality fuel leads to health and environmental problems, reduced performance and lifetime of engine and other components of an automobile. This paper presents the assessment of the quality of diesel fuel from selected filling stations in Tarkwa. Fifteen fuel samples were collected from Reseller Outlets (Gao Gao), Local Oil Marketing Companies (LOMCs) and International Oil Marketing Companies (IOMCs). Density, flashpoint and sulphur content of the sampled fuels were examined in the laboratory using hydrometer, Cleveland closed cup flash point tester and energy dispersive $\mathrm{x}$-ray fluorescence spectrometer respectively. All the tests were conducted based on the American Standard for Testing Materials (ASTM) and the results were compared with the requirements of Ghana Standards Authority (GSA). The results from the tests indicated variations in the fuel properties among all the oil marketing companies. All the samples tested were found to be within the required density limit set by GSA. Also, about $81 \%$ of the fuels had the flashpoint within the required limit. In general, all the diesel samples had high sulphur content above the GSA limit of $0.005 \mathrm{wt} \%$ ( $50 \mathrm{ppm}$ ). It is recommended that; the Government of Ghana should ensure that all oil marketing companies operate within the acceptable sulphur content limit in Ghana and should also consider reducing the acceptable sulphur content to meet international standard in the near future.

Keywords: Density; Diesel; Flash Point; Ghana Standards Authority (GSA); Sulphur

\section{Introduction}

Since the beginning of the industrial revolution, there has been fast increasing use of fossil fuels. In particular, the automobile sector has emerged as a major consumer of the fuel [1]. In developing countries like Ghana, the automobile industry is expected to grow at a faster rate with a corresponding increase in the demand for petrol and diesel. Ghana depends on imported fuel from other countries due to low refining capacity to meet transport and other energy needs. These imported fuels and in-house fuels according to
Public Eye are deem not to be well regulated due to weak regulatory standards. According to a report by the Public Eye in 2016, the weak regulatory and monitoring standards has led to the supply of poor-quality fuels or illegal petroleum products into the Ghanaian market. It was also reported that diesel contained up to 273 times more sulphur content than is permitted in Europe [2] though the sulphur levels were within the regulatory requirement of $3,000 \mathrm{ppm}$ by then. The research by Public Eye raised a lot of concerns by Ghanaians as to the quality of fuels that are imported into Ghana. Poor quality fuel may contain toxins which when emitted pose 


\section{Petroleum \& Petrochemical Engineering Journal}

immense threat to both human health and the environment.

Health studies have shown that exposure to diesel exhaust tail pipe especially from toxic diesel affects respiratory system and worsens asthma, allergies and bronchitis. In addition, there is some evidence that diesel exhaust exposure can increase the risk of heart problems, premature death and lung cancer [3]. Other effect of toxic diesel is the reduction of service life and performance of engines which also induce economic losses to the consumers [4]. To curb the above effects, strict policies should be put in place to prevent the importation of low-quality fuels into the Ghanaian market. Ghana in 2013 revised her sulphur content policy to a maximum of 3,000 ppm which was largely adhered to by importers. In April 2017, the National Petroleum Authority (NPA) directed that, all petrol and diesel imported into Ghana from $1^{\text {st }}$ July, 2017 should have a maximum sulphur content of $0.005 \%$ wt $(50 \mathrm{ppm})[3,5]$. Every new policy comes with peculiar challenges and if not monitored well, is likely to fail. Is the policy on sulphur content reduction being implemented by fuel importers after the NPA directive in 2017? This paper seeks to assess the quality of diesel obtained at pumps of some selected filling stations in Tarkwa, Ghana, to ascertain whether oil marketing companies have adhered to the new regulatory standard for sulphur content of $0.005 \%$ wt. This paper will also examine properties such as density and flash point of selected samples.

\section{Study Area}

Tarkwa, the capital of the Tarkwa-Nsuaem Municipality in the Western Region of the Republic of Ghana is a town in the south-western part of Ghana (Figure 1).

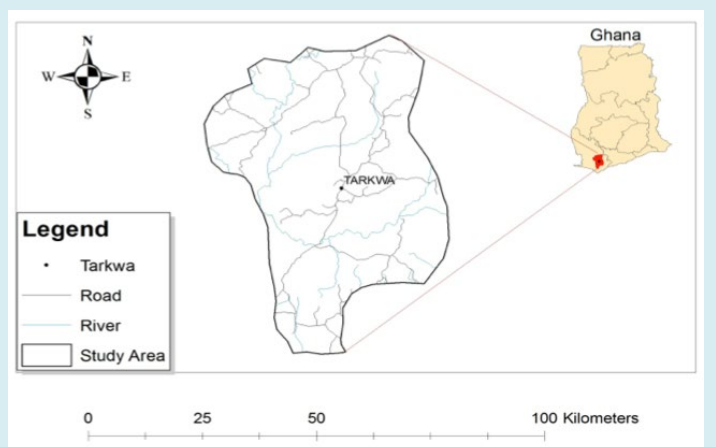

Figure 1: Map Showing the Location of Tarkwa [6].

It is located about $85 \mathrm{~km}$ from Takoradi the Regional capital and about $306 \mathrm{~km}$ from Accra. The town is endowed with gold and manganese mining companies like Goldfields Ghana Limited (GGL), Anglo-gold Ashanti (AGA) and Ghana Manganese Company (GMC). Most of the habitants are migrants from other parts of the country $[6,7]$.

\section{Diesel Fuel}

Diesel fuel is one of the three most important transportation fuels among petrol and aviation fuels propelling the growth in transportation sector in the world. Because dieselenginesareinherentlymorethermally-efficient than gasoline engines, it is expected that diesel demand and utilisation will increase more in the next few decades in the $21^{\text {st }}$ century. However, diesel fuels are considered "dirty fuels" as a result of "black smoke" from the tail pipe of some dieselpowered vehicles [8]. Diesel fuel is one of the contributors to environmental pollution worldwide. Particulate matter is created during incomplete combustion of diesel fuel. Its composition often includes chemical elements such as sulfates, ammonium, nitrates, elemental carbon, condensed organic compounds, carcinogenic compounds and heavy metals like arsenic, selenium, cadmium and zinc. This particulate matter irritates the eyes, nose, throat, and lungs, contributing to respiratory and cardiovascular illnesses $[9,10]$. The U.S. Environmental Protection Agency (EPA) and International Agency for Research on Cancer has classified diesel exhaust as a potential human carcinogen. Exposure to high levels of diesel exhaust has been shown to cause lung tumors in rats, and studies of humans routinely exposed to diesel fumes indicate a greater risk of lung cancer. Diesel emissions also contribute to pollution of water and soil; reductions in visibility and global climate change $[11,12]$.

Increasing demand for diesel fuels and rising standards for better fuel specifications to reducing emissions have resulted in heightened interest worldwide on chemistry of the fuel [8]. The hydrocarbons types in diesel fuel are typically similar to that of petrol (gasoline) however, the carbon number and molecular weight are higher. The boiling range of diesel is within $180{ }^{\circ} \mathrm{C}$ to $370{ }^{\circ} \mathrm{C}$ whilst carbon number range lies within $\mathrm{C} 10$ to $\mathrm{C} 19$. Again, due to the difference in the nature and composition of diesel fuel, it has a different refining processes requirement compared to petrol [13]. Diesel fuel is sometimes called "diesel oil" because of how oily it is. It also possesses a strong unique smell. Diesel fuels are mostly assessed based on standards like: heat value, specific gravity, flash point, volatility, pour point; cloud point, viscosity, carbon residue, sulphur content, fungus and bacterial contaminants; distillation, total sediment, polycyclic aromatics ( +2 rings), cetane index, cetane number, multifunctional additives dosage, cetane improver presence, oxidation and water [14-17].

\section{Diesel Fuel Adulteration}

Adulteration is defined as an unlawful introduction of foreign substance into a fuel substance that affects the requirements and specifications of the product. These foreign substances are called adulterants [18,19]. Adulterated fuel 


\section{Petroleum \& Petrochemical Engineering Journal}

aside affecting the service life of engines, causes severe environmental pollution such as emission of sulphur oxide derivatives $[4,20]$. The choice of a particular adulterant is based on the monetary gains, easy blending ability, availability and similarity of the chemical and physical properties of the fuel to the adulterant. In most cases, petroleum-based adulterants satisfy these requirements for the adulteration of diesel $[21,22]$. Kerosene is reported to be the most popularly used adulterant among the common industrial solvents and used lubricants [20,23-25]. Adulteration of diesel using petrochemical based products is gaining root in developing countries. The similarity in chemical properties of the fuel and the adulterant make distinguishing difficult, leading to complications in identification and quantification of the adulterants [20].

\section{Materials and Methods}

\section{Materials}

A 1.5 L of diesel was obtained from fifteen (15) filling stations in Tarkwa, Ghana. These included Reseller Outlets (Gao Gao), Local Oil Marketing Company (LOMCs) and International Oil Marketing Company (IOMCs). The tested values were compared with the requirements of Ghana Standards Authority (GSA) (Table 1).

\begin{tabular}{|c|c|}
\hline Properties & GSA \\
\hline Flashpoint $\left({ }^{\circ} \mathrm{C}\right)$ & Min. 55 \\
\hline Sulphur content $(\% \mathrm{wt})$ & Max. 0.005 \\
\hline Density at $15^{\circ} \mathrm{C}\left(\mathrm{kg} / \mathrm{m}^{3}\right)$ & $820-870$ \\
\hline
\end{tabular}

Table 1: Standard Requirement for Diesel Fuel [5].

\section{Methods Used}

This paper used density, flash point and sulphur content approach to determine the quality of diesel fuel. The experiment was conducted in line with ASTM and the results were compared with the standards of GSA.

Measurement of Density: Density is the mass of a liquid per unit volume of liquid at $15^{\circ} \mathrm{C}$ and $101.325 \mathrm{kPa}$ with the standard unit of measurement being $\mathrm{kg} / \mathrm{m}^{3}$. The density of the samples was measured with hydrometer (Figure 2).

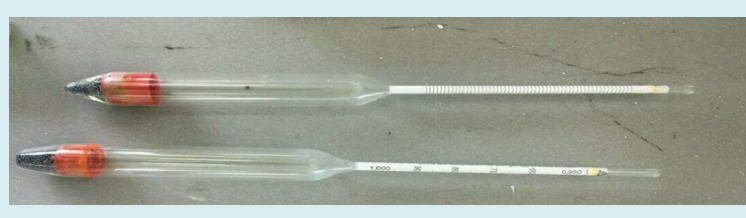

Figure 2: Hydrometer.
Measurement of Flash Point: A fuel's flash point is the lowest temperature at which vapours of a volatile material will ignite, when given an ignition source [26]. The flash point has no effect on engine performance or on its ignition qualities. It is specified simply as an index of fire hazard. A fuel oil with an extremely low flash point is dangerous to store and handle. Diesel fuel flash points are not indications of how they will ignite in an engine cylinder, however, this depend on the ignition quality of the fuel. For example, diesel with very low flash point, would be a very poor diesel fuel due to its ignition quality [14]. There are two basic types of flash point measurement; open cup and closed cup. The flash point of the fuel was determined by Cleveland closed cup method (Figure 3).

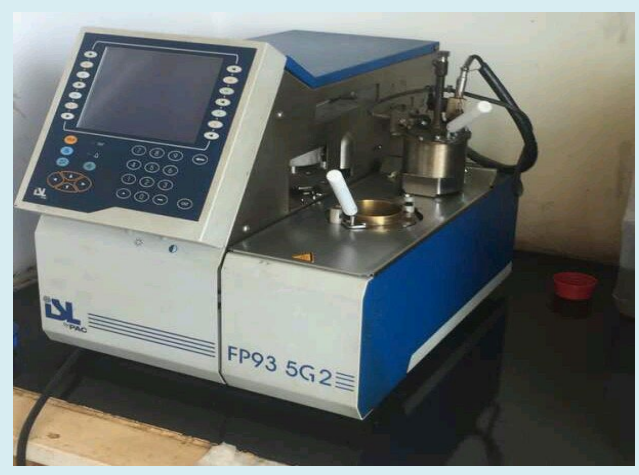

Figure 3: Cleveland Closed Cup Flash Point Tester.

\section{Measurement of Sulphur Content Using Energy Dispersive} X-Ray Fluorescence: Sulphur occurs naturally in crude oil and is therefore found in diesel and gasoline fuels. When fuel is combusted, the sulphur in fuel causes the release of environmentally harmful compounds such as sulphur oxides and sulphate particles that can contribute to decreased air quality and thus have negative environmental and health effects. The wear of pistons, rings, and cylinders in a diesel engine generally increases when there is an excessive amount of sulphur in the fuel. Excess sulphur content also causes varnish to form on the piston skirt and creates oil sludge in the engine crankcase. Sulphur also combines with water to form corrosives as a result of the combustion process. These corrosives can etch finished surfaces, accelerate engine wear, attack softer metals such as bearings and deteriorate engine oil. Similar corrosion damage from sulphur is frequently found in the engine's exhaust system [14]. Sulphur test method provides rapid and precise measurement of total sulphur in petroleum product (diesel, petrol etc.) with a minimum of sample preparation. A typical analysis time is two to four minutes per sample. The test was conducted with Energy Dispersive X-Ray Fluorescence Spectrometer (Figure 4). 


\section{Petroleum \& Petrochemical Engineering Journal}

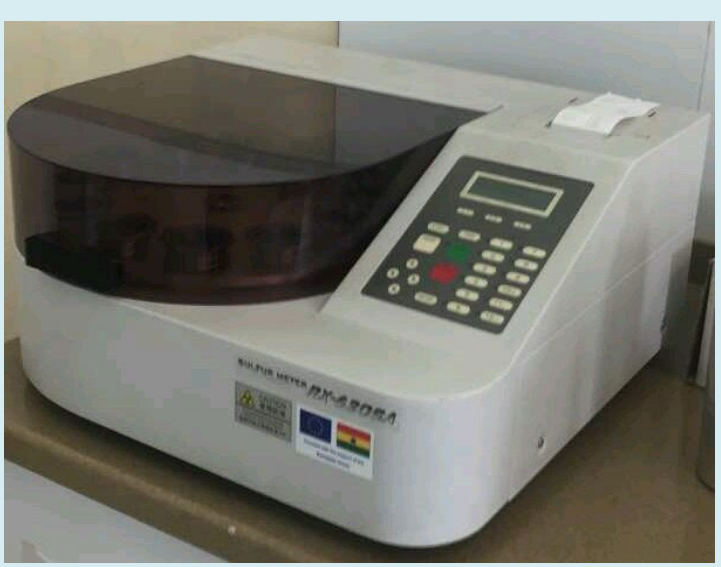

Figure 4: Energy Dispersive X-Ray Fluorescence Spectrometer.

\section{Results and Discussion}

\section{Results}

Table 2, presents the results of the laboratory experiments conducted on the flash point, sulphur content and the density of diesel obtained from Reseller Outlets (Gao Gao), Local Oil Marketing Company (LOMCs) and International Oil Marketing Company (IOMCs) respectively in Tarkwa, Ghana.

\begin{tabular}{|c|c|c|c|}
\hline $\begin{array}{c}\text { Sample } \\
\text { Codes }\end{array}$ & $\begin{array}{c}\text { Flashpoint } \\
\text { (-C) }\end{array}$ & $\begin{array}{c}\text { Sulphur } \\
\text { Concentration } \\
\text { (\% wt) }\end{array}$ & $\begin{array}{c}\text { Density } \\
\left(\mathbf{k g} / \mathbf{m}^{\mathbf{3}} \text { ) at }\right. \\
\mathbf{1 5} \mathbf{~} \mathbf{C}^{\mathbf{0}}\end{array}$ \\
\hline A & 62 & 0.0161 & 823.2 \\
\hline B & 55 & 0.0247 & 821.5 \\
\hline C & 70 & 0.0117 & 826.5 \\
\hline D & 62 & 0.0118 & 821.8 \\
\hline E & 66 & 0.0134 & 821.7 \\
\hline F & 66 & 0.0152 & 820.6 \\
\hline G & 66 & 0.0135 & 821.9 \\
\hline H & 61 & 0.0140 & 820.8 \\
\hline I & 37 & 0.0152 & 822.5 \\
\hline J & 63 & 0.0203 & 821.8 \\
\hline K & 65 & 0.0060 & 836.0 \\
\hline L & 37 & 0.0143 & 826.7 \\
\hline M & 51 & 0.0079 & 820.2 \\
\hline N & 69 & 0.0142 & 822.7 \\
\hline O & 61 & 0.0126 & 824.3 \\
\hline
\end{tabular}

Table 2: Results for Flashpoint, Sulphur Concentration and Density Tests for Diesel Fuel from Selected Filling Stations in Tarkwa.

\section{Discussion}

Density: Figure 5 shows the densities of all the diesel fuels. Letters $\mathrm{A}$ to $\mathrm{O}$ represent the names of the selected filling stations in Tarkwa, Ghana. The density of the diesel fuel is an important quality indicator for automobiles because it controls the amount of fuel that is compressed and burned in the combustion chamber. Figure 5 shows that, all samples tested were within the regulated range prescribed by GSA $\left(820-870 \mathrm{~kg} / \mathrm{m}^{3}\right)$, though there were some significant variations in the density values. Comparing the density values of diesel fuels of the oil marketing companies, it was observed that, averagely, the LOMCs had density values higher than the Gao Gao outlets and IOMCs. According to Yadav, et al. [23] density of diesel fuel can be within the prescribed value even at higher adulteration by kerosene and there would not be any appreciable changes in the density. To check for the quality of the fuel, it is important that other parameters are determined alongside with the density of the fuel.

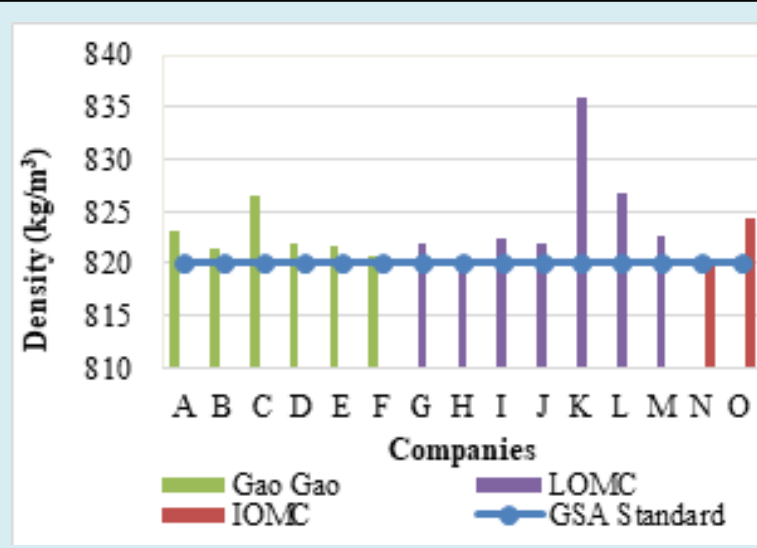

Figure 5: Density of the Diesel Fuels.

Flashpoint: The flashpoint property of any diesel fuel is very important to determine the quality of the fuel. Figure 6 shows the flashpoint for all the diesel fuels from the selected filling stations.

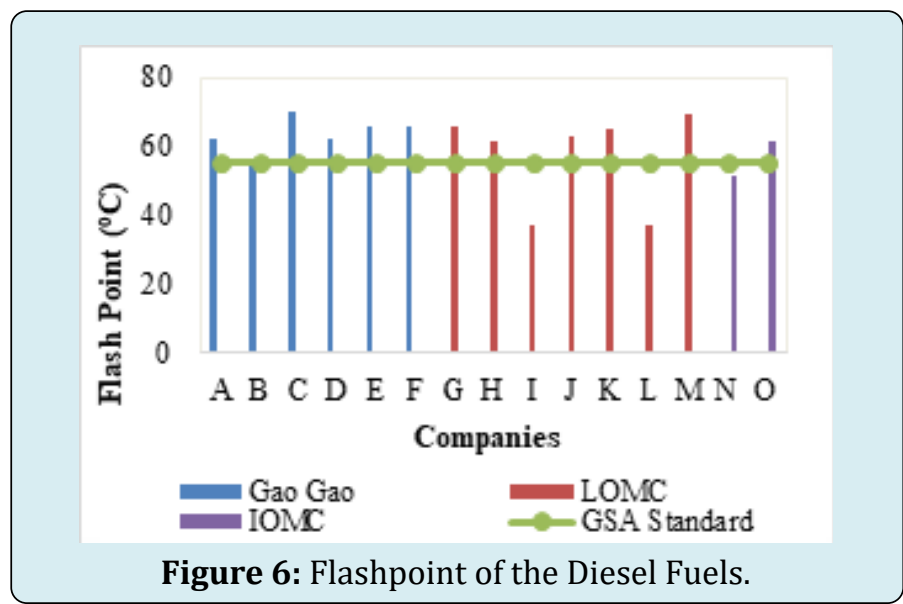




\section{Petroleum \& Petrochemical Engineering Journal}

From Figure 6, about $80 \%$ of the diesel samples were within the minimum value of $55^{\circ} \mathrm{C}$ as stipulated by the GSA (Min. $55^{\circ} \mathrm{C}$ ). All the fuels from the Gao Goa outlets met GSA required limit as compared to diesel samples from LOMCs and IOMCs. About $28.6 \%$ and $50 \%$ of diesel fuels from LOMCs and IOMCs respectively failed the required standard set up by GSA. It was also observed that, the Gao Gao outlets had a better flash point values compared to the LOMCs and IOMCs. This observation contradicts the perception in Ghana that diesel sold at Gao Gao outlets are of poor quality in terms of all the quality indicators. High flash point means a safe fuel. This property is important for transportation and safety. Low flash point of diesel fuel increases the risk of explosion of the diesel tank when a mechanical shock such as collision occurs which can endanger the lives of people [27].

Sulphur Content: Sulphur content in fuel is a major problem and therefore most countries are making legislations to meet fuels with ultra-low sulphur content. Figure 7 shows the sulphur content of diesel fuels from Gao Gao outlets, IOMCs and LOMCs. After the test for the fifteen (15) diesel samples, the results showed that all the samples from the oil marketing companies had their sulphur levels higher than the maximum requirement for sulphur which is $0.005 \% \mathrm{wt}$ (Figure 7).

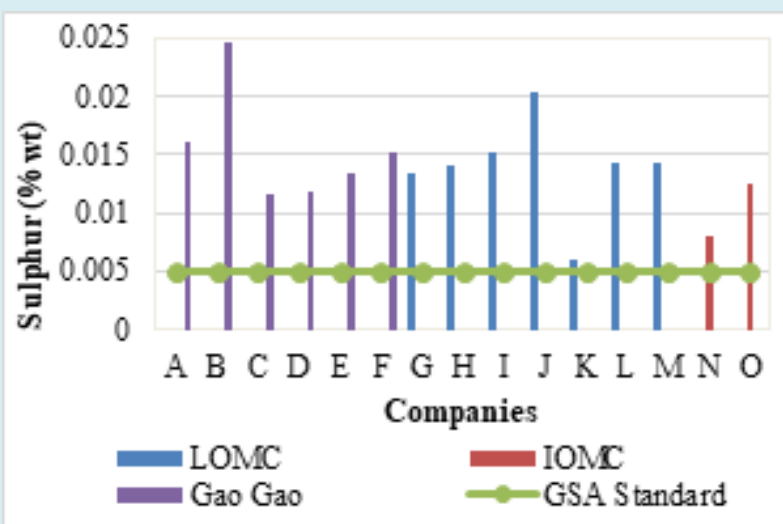

Figure 7: Sulphur Content of the Diesel Fuels.

However, one of the LOMCs recorded a sulphur content of $0.006 \%$ wt which is slightly above the recommended value. In general, IOMCs had better sulphur content, followed by LOMCs and the Gao Gao outlets. Most cars in Africa especially trucks and buses and huge power generating plants run on diesel with more polluting rate than gasoline. High sulphur fuels do not only lead directly to higher emissions of pollutants, they are also corrosive, destroying advanced emission control technologies in vehicles $[2,28]$. The amount of sulphur in diesel fuel is directly linked to the amount of pollution produced when the fuel is burned in an engine. When diesel fuel is burned in engines, the emissions that result contributes to air pollution that has serious human health and environmental effects. High sulphur emission also results in environmental problems such as acid rain, destruction of the ozone layer and formation of particulate matter or soot. Acid rain results in the acidification of aquatic systems, increasing soil acidity and damage to vegetation [29].

\section{Conclusions and Recommendations}

From the study, the following conclusions were drawn:

1. There were large variations for the fuel properties among the oil marketing companies.

2. The densities of all the selected oil marketing companies were within GSA requirement. Averagely the LOMCs had density values higher than both the Gao Gao outlets and IOMCs.

3. About $80 \%$ of the selected oil marketing companies had the flashpoints of their respective fuels within the limit stipulated by the GSA. The Gao Gao outlets had a better flash point values compared to the LOMCs and IOMCs and this observation contradicts the perception in Ghana that diesel sold at Gao Gao outlets are of poor quality and unsafe to handle.

4. All the oil marketing companies had the sulphur content of the diesel fuel above the maximum value required by GSA. This indicates that majority of the oil marketing companies in Tarkwa are not complying with the directives from the regulator. Generally, IOMCs had better sulphur content, followed by LOMCs and the Gao Gao outlets.

The following recommendations are made as a result of the findings from the experiment:

1. The Government of Ghana should ensure that oil companies operate within the acceptable sulphur content limit in Ghana.

2. The Government of Ghana should also consider reducing the acceptable sulphur content to meet international standard of $10 \mathrm{ppm}$ in the near future

\section{References}

1. Gupta A, Sharma RK (2010) A New Method for Estimation of Automobile Fuel Adulteration. In: Villanyi V (Ed.), Air Pollution. InTech Publishers 16: 357-370.

2. Anon (2016a) Dirty Fuel: Swiss Commodity Traders Flood Africa with Toxic Fuel. Public Eye.

3. Anon (2017) NPA Revises Imported Fuel Sulphur Content.

4. Anon (2019) Detection of Adulterated Diesel. 


\section{Petroleum \& Petrochemical Engineering Journal}

5. Wilson J (2017) Overview of the Impact of Fuel Quality on Soot-Free Bus Project in Accra. Institute of Environmental Studies, Accra, Ghana, pp: 15.

6. Nyarko C (2016) Modelling Prevalence and Incidence Rates of Chlamydia Trachomatis Infection in Western Region of Ghana. PhD Thesis, University of Mines and Technology, Tarkwa, Ghana, pp: 33.

7. Akabzaa T, Abdulai D (2001) Impact of Mining Sector Investment in Ghana: A Study of the Tarkwa Mining Region. Geotechnical software, pp: $71 \mathrm{pp}$.

8. Song C, Hsu CS, Mochida I (2000) Chemistry of Diesel Fuels. ${ }^{\text {st }}$ (Edn.), Taylor \& Francis, New York, USA.

9. Anon (1997) Particulate Matter (TSP and PM-10) in Minnesota. Minnesota Pollution Control Agency.

10. Anon (2008) Diesel Engine and Public Health.

11. Anon (2002) Health Assessment Document for Diesel Engine Exhaust. National Center for Environmental Assessment, Office of Research and Development, US EPA, Washington D.C., pp: 9-11.

12. Lloyd AC, Cackette TA (2001) Diesel Engines: Environmental Impact and Control. J Air Waste Manag Assoc 51(6): 809-847.

13. Aleme HG, Corgozinho CNC, Barbeira PJS (20100) Diesel Oil Discrimination by Origin and Type Using Physicochemical Properties and Multivariate Analysis. Fuel 89(11): 3151-3156.

14. Anon (2016b) Diesel Technology. $8^{\text {th }}$ (Edn.), G-W Online Textbooks.

15. Jersha FV, Udaykiran PA, Ganesan K (2015) Fuel Adulteration Detection System. Indian Journal of Science and Technology 8(S2): 90-95.

16. Kher S, Chaubey S, Kishore J, Oak SM (2013) Detection of Fuel Adulteration with High Sensitivity using turnaround Point Long Period Fiber Gratings in B/Ge Doped Fibers. IEEE Sensors Journal 13(11): 4482-4486.

17. Kaiser CR, Borges JL, dos Santos AR, Azevedo DA, D'Avila LA (2010) Quality Control of Gasoline by 1H NMR: Aromatics, Olefinics, Paraffinics, and Oxygenated and Benzene Contents. Fuel 89(1): 99-104.

18. Gawande AP, Kaware JP (2013) Fuel Adulteration Consequences in India: A Review. Scientific Reviews \&
Chemical Communications 3(3): 161-171.

19. Obodeh 0, Akhere NC (2010) Experimental Study on the Effects of Kerosene-doped Gasoline on GasolinePowered Engine Performance Characteristics. Journal of Petroleum and Gas Engineering 1(2): 37-40.

20. Kulathunga DR, Mahanama KRR (2013) Finger Printing Diesel and Petrol Fuels for Adulteration in Sri Lanka. Journal of the National Science Foundation of Sri Lanka 41(4): 287-292.

21. Bharath LV, Himanth M (2017) Review on the Detection of Fuel Adulteration through Sensor based Techniques. International Journal of Scientific and Research Publications 7(9): 447-451.

22. Babu V, Krishna R, Mani N (2017) Review on the Detection of Adulteration in Fuels through Computational Techniques. Materialstoday: Proceedings 4(2A): 17231729.

23. Yadav SR, Murthy VK, Mishra D, Baral B (2005) Estimation of Petrol and Diesel Adulteration with Kerosene and Assessment of Usefulness of Selected Automobile Fuel Quality Test Parameters. International Journal of Environmental Science \& Technology 1(4): 253-255.

24. Taksande A, Hariharan C (2006) Synchronous fluorescence Method to Check Adulteration of Petrol and Diesel by Kerosene. Spectroscopy Letters 39(4): 345356.

25. Kalligeros S, Zannikos F, Stournas S, Lois E (2003) Fuel Adulteration Issues in Greece. Energy 28(1): 15-26.

26. Arunachaleshwara PR, Rajesh K, Sreeraj GN, Cifin F, Nishanth B, et al. (2017) Effect of Free Water and Rust on Flash Point of Diesel. International Journal of Engineering and Science 7(2): 21-24.

27. Thilagan J, Gayathri R (2014) Low Flash Point of Diesel in India and Fire Accidents in Transport Vehicles -An analysis. International Journal of Green and Herbal Chemistry 3(2): 532-535.

28. Zhang K, Hu J, Gao S, Liu Y, Huang X, et al. (2010) Sulfur Content of Gasoline and Diesel Fuels in Northern China. Energy Policy 38(6): 2934-2940.

29. Ramalingam M, Fuad AA (2015) Short Communication: Sulphur Levels and Fuel Quality in Peninsular Malaysia. ASEAN J Sci Technol Dev 32(1): 52-59. 